\title{
Pitkittyneen työkyvyttömyyden eritahtinen kehittyminen eri sosioekonomisissa ryhmissä läpi elinkaaren
}

\section{TYÖKYKY YKSILÖN JA YMPÄRISTÖN RESURSSIEN VUOROVAIKUTUKSEN LOPPUTULEMANA}

Aloitan kysymällä sinulta, millainen on työkykysi tänään? Miten se on kenties kehittynyt viimeisen puolen vuoden aikana? Entä millaisten tekijöiden uskot vaikuttaneen siihen, että työkykysi on sillä tasolla, kuin se nyt on? Oma työkykyni on juuri tällä hetkellä ainakin kohtuullinen. Tilanteeseen nähden kenties jopa hyvä. Se on myös voimakkaasti ailahdellut viimeisen puolen vuoden aikana. Tähän on vaikuttanut monikin tekijä - niin muutokset työelämässä kuin sen ulkopuolellakin.

Työhyvinvointi ja työkyky ovat nousseet aivan uudella tavalla ajankohtaiseksi koronapandemian myötä. Se on tehnyt näkyväksi työhyvinvointiimme vaikuttavia tekijöitä, niin työelämässä kuin sen ulkopuolellakin, joihin emme kenties aiemmin ole samalla tavalla kiinnittäneet huomiota. Tai kenties nämä tekijät ovat saaneet aivan uuden merkityksen.

Työkyvystä puhuttaessa, onkin tärkeää ymmärtää, ettei sitä voida tarkastella sairauskeskeisesti vain yksilön terveytenä tai sairautena. Sen sijaan kysymys on laajemmasta kokonaisuudesta, yksilön ominaisuuksien, elämäntilanteen, työn ja laajemman yhteiskunnallisen kehyksen yhteensovittamisesta. Työkykymme on siis näiden eri tekijöiden välisen jatkuvan vuorovaikutuksen tulosta. Täysissäkään ruumiin ja sielun voimissa oleminen ei takaa työelämässä menestymistä, jos työpaikkaa ei ole tai työpaikalla käytännöt eivät toimi.

Tämä herättääkin kysymyksen - olemmeko me oikeastaan koskaan 100 prosenttisen työkykyisiä tai työkyvyttömiä? Onko meidän jokaisen kohdalla kysymys oikeastaan liukuvasta skaalasta, jossa työkykymme aste vaihtelee elinkaaremme aikana vuosittain, kuukausittain tai jopa useasti päivässä?
Sosiologisin termein, olemme kaikki varustettuina erilaisilla yksilö- ja ympäristötason resursseilla, jotka vaikuttavat työssä jaksamiseemme, sekä kykyymme vastata erilaisiin elämän muutostilanteisiin. Yksilötason resursseilla voidaan tarkoittaa esimerkiksi persoonallisuutta, terveyttä, koulutus- ja tulotasoa tai työmarkkina-asemaa. Asuinalue ja työympäristö ovat taas esimerkkejä ympäristötason resursseista. (1.) Nämä resurssit jakautuvat epätasaisesti väestöryhmien kesken. Olemme monella tapaa eriarvoisessa asemassa sen suhteen, millaisia mahdollisuuksia meillä on ylläpitää ja edistää työkykyämme tai selviytyä vastoinkäymisistä ja muutostilanteista elämässä. Esimerkiksi koronapandemia on kohdellut sosioekonomisia ryhmiä eri tavoin ja samalla nostanut sosioekonomiset terveyserot jälleen pintaan.

Suomenkin kaltaisessa hyvinvointivaltiossa sosioekonomiset terveyserot vallitsevat yhä, vaikka terveyserojen kaventaminen on ollut poliittisena agendana jo puoli vuosisataa. Matalasti koulutetuilla, matalatuloisilla ja matalaan sosioekonomiseen asemaan kuuluvilla on edelleen enemmän terveysongelmia ja matalampi elinajanodote. Heillä on myös enemmän työkyvyttömyyttä, pidempiä sairauspoissaoloja ja he poistuvat työelämästä ennenaikaisesti työkyvyttömyyseläkkeelle korkeakoulutettuja ja korkeatuloisia useammin. (2.)

Erilaisilla työvoimapoliittisilla, sosiaaliturvaja eläkejärjestelmillä on vaikutusta siihen, kuinka näitä epätasa-arvoisia lähtökohtia tasoitetaan tai häivytetään. Työhyvinvointi, työssä jaksaminen ja työurien pidentäminen ovatkin jo pitkään olleet esillä niin julkisessa keskustelussa kuin politiikassakin. Viime aikoina julkisessa ja poliittisessa keskustelussa onkin siirrytty täydellisen työkyvyttömyyden ehkäisystä kohti jäljellä ole- 
van työkyvyn ylläpitämiseen. Esimerkiksi monet interventiot ja poliittiset ohjelmat pyrkivät nykyään jäljellä olevan työkyvyn ylläpitoon ja osatyökyisten parempaan osallistamiseen. OTEhanke, sote- ja sosiaaliturvauudistus tai vaikkapa aktiivimallit ovat esimerkkejä tällaisista ohjelmista. Oikeastaan näissä kaikissa keskitytään olemassa olevan työkyvyn vahvistamiseen ja työllistymisen edistämiseen. Lähtökohtana kaikissa on, että jokainen on työkykyinen johonkin työhön, kunhan se suunnitellaan henkilön tarpeiden mukaan ja hänelle annetaan riittävästi tukea.

Tällaisten tavoitteiden onnistumiseksi, on tunnistettava niitä vaiheita, jolloin työkyvyttömyyden pitkittymistä olisi hedelmällisintä ehkäistä.

\section{TUTKIMUSASETELMA JA AINEISTO}

Väitöskirjassani pureudun juuri tähän teemaan. Tutkin pitkittyneen työkyvyttömyyden kehittymistä, siihen liittyviä riskitekijöitä sekä niissä ilmeneviä sosioekonomisia eroja vahvasti prosessimaisuuden näkökulmasta. Lähtökohtanani on, että pitkittyneen työkyvyttömyyden kehittyminen on jo prosessi itsessään. Pitkittyneen työkyvyttömyyden kehittyminen on dynaamista: työkyvyttömyys ja siihen liittyvät riskitekijät ovat jatkuvassa muutoksessa elinkaaremme aikana. Nämä prosessit kehittyvät eri tavoin yksilöiden välillä, riippuen muun muassa heidän sosioekonomisesta asemastaan. Lisäksi, nämä ovat osa sosioekonomisten työkyky- ja terveyserojen tuottamisen prosessia.

Väitöskirjani koostuu neljästä tieteellisestä artikkelista. Jokaisessa artikkelissa käytetään laadukasta väestöä edustavaa rekisteriaineistoa. Käyttämällä väestöä edustavia rekisteriaineistoja pääsen pureutumaan ilmiöihin, joita olisi vaikea saada esille vain analysoimalla esimerkiksi kohdennetuille ryhmille tehtyjä kyselyitä. Menetelminä käytetään elinaikamalleja ja ryhmäperusteista trajektorianalyysia. Seuraamalla henkilöitä yli vuosien, eli tieteellisemmin sanoen käyttämällä pitkittäisasetelmaa, on minulla mahdollisuus seurata pitkittyneen työkyvyttömyyden kehittymistä pitkällä ajanjaksolla.

\section{VÄITÖSKIRJAN KESKEISET TULOKSET}

Ylisukupolvista periytymistä voidaan pitää ajallisesti ensimmäisenä pitkittyneen työkyvyttömyyden prosessina. Pitkittyneen työkyvyttömyyden kehittyminen voi alkaa jo kohdusta ja lapsuudesta. Tämä on etenkin pitkässä juoksussa erittäin haitallista - mitä varhaisemmassa vaiheessa työkyky merkittävästi heikkenee, sen vakavammat ovat sen seuraukset niin yksilölle kuin yhteiskunnallekin. Perinnöllisten sairauden lisäksi perheiden sosioekonomiset resurssit vaikuttavat siihen, millaisia sosiaalisia riskejä perheet kohtaavat ja miten he niistä selviävät. Perheympäristö tarjoaa erilaisten taloudellisten ja koulutuksellisten resurssien lisäksi esimerkiksi sosiaalisia verkostoja, arvoja ja esimerkiksi kulttuurisia resursseja kuten terveydenlukutaitoa. Koska emme voi valita, millaiseen perheeseen synnymme, on tämä myös lähtölaukaus työkyvyttömyyteen liittyvälle sosiaaliselle eriarvoisuudelle.

Ensimmäisessä artikkelissa tarkastellaan vanhempien tulojen ja koulutuksen sekä lapsen oman koulutustason yhteyttä lapsen työkyvyttömyyseläkkeelle siirtymiseen 19-27-vuotiaana. Tulokset osoittavatkin, että perhetausta vaikuttaa nuorten aikuisten todennäköisyyteen siirtyä työkyvyttömyyseläkkeelle. Korkeasti koulutettujen ja korkeatuloisten vanhempien lapset siirtyivät epätodennäköisemmin työkyvyttömyyseläkkeelle nuorina aikuisina. Lisäksi korkeakoulutettujen ja korkeatuloisten lapset ovat työkyvyttömyyseläkejaksonsa jälkeen useammin työelämässä tai opiskelemassa, kuin matalasti koulutettujen ja matalatuloisten vanhempien lapset. Kertooko tämä kenties siitä, että korkeakoulutetuilla vanhemmilla on paremmat edellytykset, tai resurssit, tunnistaa ja tarttua lastensa työkykyyn liittyviin ongelmiin? Tämä vaatisi jatkotarkastelua.

Tarkasteltaessa pitkittyneen työkyvyttömyyden kehittymistä myöhemmin työelämässä, yksi tärkeimmistä prosesseista koskee sairauspäivärahapäivien kertymistä. Toisessa artikkelissa tarkastellaan sairauspäivärahakauden pituuden yhteyttä työkyvyttömyyseläkkeelle siirtymiseen eri sosioekonomisissa ryhmissä 25-63-vuotiailla miehillä ja naisilla. Kun sairauspäivärahat karttuvat, työkyvyttömyyseläkkeelle siirtymisen riski kasvaa. Mutta riski ei kasva tasaisesti eri ammattiryhmissä. Sen sijaan, väitöskirjani löydökset osoittavat riskin kasvavan kaikkein nopeimmin ylemmillä toimihenkilöillä. Pitkittyneen työkyvyttömyyden kehittyminen tapahtuu siis eri ammattiryhmissä hyvin eri tahtisesti.

Syitä tähän voidaan vain arvuutella. Kenties ylemmät toimihenkilöt eivät ole pakotettuja ly- 
hyempiin sairauslomiin työkyvyttömyyden iskiessä, ja vasta työkyvyttömyyden ollessa tarpeeksi vakava, siirtyvät he pitkille sairauspäivärahajaksoille. Ylemmillä toimihenkilöillä saattaa olla paremmat mahdollisuudet niin sanotusti tuunata työtään työkykyään vastaavaksi. Ammattiryhmittäiset erot työkyvyttömyyseläkkeelle siirtymisessä saattavat selittyä myös eroissa sairauspoissaolojen ilmoituskäytännöissä ja taloudellisissa kannustimissa.

Sairauspäivärahan pituuden lisäksi toinen tärkeä tekijä on diagnoosi. Kolmannessa artikkelissa tarkastellaan sairauspäivärahakauden diagnoosin yhteyttä työkyvyttömyyseläkkeelle siirtymiseen eri diagnooseilla, eri sosioekonomisissa ryhmissä 25-63-vuotiailla miehillä ja naisilla. Erityisesti tuki- ja liikuntaelinsairauksien ja mielenterveyden häiriöiden perusteella myönnetty sairauspäiväraha on voimakkaasti yhteydessä työkyvyttömyyseläkkeelle siirtymiseen. Viime aikoina näistä etenkin mielenterveyden häiriöt sairauspäivärahan ja työkyvyttömyyseläkkeen syynä ovat yleistyneet.

Tutkimuksistani ilmenee, että sairauspäivärahan saaminen tuki- ja liikuntaelinsairauksien diagnoosilla on etenkin naisilla ja alemmilla toimihenkilöillä yhteydessä työkyvyttömyyseläkkeelle siirtymiseen. Miehillä etenkin ylemmillä toimihenkilöillä ja yrittäjillä taas mielenterveyden häiriön perusteella myönnetty sairauspäiväraha ennustaa työkyvyttömyyseläkettä. Toisaalta myös sairauspäivärahan saaminen hengityselinten ja verenkiertoelinten sairaudet kasvattivat erityisesti jollain muulla diagnoosilla myönnetyn työkyvyttömyyseläkkeelle siirtymisen riskiä. Toisin sanoen, nämä sairaudet ovat yleisemmin muiden sairauksien kanssa esiintyviä diagnooseja. Näissä kuitenkin ammattiryhmittäiset erot olivat pieniä.

Loppujen lopuksi, suurin työkyvyttömyysriski kasautuu kuitenkin erityisesti työelämän ulkopuolella oleville ja työntekijäammateissa työskenteleville. Etenkin ylemmät toimihenkilöt sen sijaan ovat lähtökohtaisesti suojassa työkyvyttömyyteen liittyviltä riskeiltä. Tulokset siis osoittavat, että pitkittyneen työkyvyttömyyden kehittyminen on vahvasti yhteydessä ammattiryhmään, jolloin tämä pitäisi huomioida myös työkyvyttömyyttä ehkäiseviä keinoja suunnitellessa.

Työoloilla on keskeinen merkitys pitkittyneen työkyvyttömyyden kehittymiseen, sekä siinä il- meneviin sosioekonomisiin eroihin. Vaikka fyysisesti raskas työ on edelleen vahvimmin yhteydessä työkyvyttömyyteen, voidaan työn psykososiaalisen työympäristön merkityksen odottaa kasvavan työn murroksen yhteydessä. Parhaillaan maailmaa kurittava koronapandemia on kenties ajankohtaisin esimerkki työn murroksesta, joka on aivan uudella tavalla nostanut erityisesti psykososiaalisen työympäristön merkityksen työhyvinvoinnille. Esimiestyö, työkaverit sekä vaatimukset ja vaikutusmahdollisuudet työssä ovat viimeisimpien kyselytulosten mukaan nousseet tärkeiksi tekijöiksi työssä jaksamiselle. $(3,4$. Työpaikkojen psykososiaalisen työympäristön lisäksi työpaikan kyky muuntaa ympäristöään vallitsevassa tilanteessa on tuoneet näkyviksi työhyvinvointiin liittyviä sosioekonomisia eroja.

Neljännessä artikkelissa tarkastellaan ruotsalaisella rekisteriaineistolla työn vaatimusten ja vaikutusmahdollisuuksien tason yhteyttä työkyvyttömyyspäivien kertymiseen miehillä ja naisilla. Vaikka tutkimukseni eivät olekaan keskittyneet varsinaisesti pandemian vaikutusten analysointiin, antavat tutkimustulokseni näkökulmia ja työkaluja ilmiön seurausten ymmärtämiseen. Väitöskirjani tulokset osoittivat, että erityisesti passiivinen työ - eli työ, jossa työntekijällä on vain vähäisiä mahdollisuuksia vaikuttaa työtehtäviinsä, yhdistettynä mataliin työn vaatimustasoihin, sekä yleisesti työ, jossa vaikutusmahdollisuuksien ja vaatimustason epätasapaino on suuri - ovat yhteydessä korkeaan työkyvyttömyyspäivien kertymiseen. Sen sijaan aktiivinen työ - eli työ, jossa työntekijä voi vaikuttaa työtehtäviinsä paljon, ja hän kohtaa haasteita työssään - on yhteydessä vähäisiin työkyvyttömyyseläkepäivien kertymiseen.

Tämä asettaa ihmisiä eriarvoisiin asemiin työmarkkinoilla. Esimerkiksi matalapalkka-alat kuuluvat usein passiivisen työn kategoriaan, jolloin näillä aloilla kyky vastata työn murroksen tuomiin haasteisiin ovat matalat. Tämä taas voi jopa voimistaa jo aiemmin selkeitä työhyvinvointiin liittyvää eriarvoisuutta.

\section{LOPUKSI}

Ymmärtämällä työkyvyttömyyden syitä, sen takana toimivia monimuotoisia prosesseja, sekä näiden yhteyttä sosioekonomiseen asemaan, voitaisiin työkyvyttömyyttä ehkäistä entistä varhaisemmin ja tehokkaammin. Tämä on ajankohtaista 
etenkin juuri nyt, työn murroksen sekä erilaisten järjestelmäuudistusten keskellä. Sekä järjestelmäuudistukset että koronan kaltaiset pandemiat nostavatkin keskiöön sekä yksilöiden työkyvyn, että työpaikkakohtaisten työkykyä ylläpitävien järjestelmien kestävyyden nyt ja tulevaisuudessa. Miten onnistumme ylläpitämään yksilön työkykyä ja toisaalta ehkäisemään työkyvyttömyyttä jatkossa? Miten onnistuisimme tässä mahdollisimman tasa-arvoisesti? Millaisia työkykyä tukevia käytäntöjä ja järjestelmiä tulemme tulevaisuudessa tarvitsemaan?

Tuoreimmat selvitykset osoittavat, että esimerkiksi matalan kynnyksen psykoterapiapalvelut, työn muokkaaminen henkilökohtaisemmin yksilön voimavarojen ja elämäntilanteen tarpeiden mukaan sekä uraohjaukseen liittyvät palvelut voivat auttaa ehkäisemään työkyvyttömyyden pitkittymistä. (4).

Toisin sanoen, tulevaisuudessa työkykyhaasteiden ratkaisemiseksi tarvitsemme siis yhteistyötä sekä yksilöiden, työpaikkojen että erilaisten järjestelmien välillä. Tavoitteena on, että yhä useampi meistä voisi todeta työkykynsä olevan vähintäänkin "kohtuullinen, tai tilanteeseen nähden jopa hyvä”.

\section{LÄHTEET}

1. Mackenbach J.P. Health inequalities: persistence and change in European welfare states. IsoBritannia: Oxford University Press; 2019.

2. Karvonen S, Martelin T, Kestilä L ja Junna L. Tulotason mukaiset terveyserot ovat edelleen suuria. Suomen sosiaalinen tila 3/2017. Tutkimuksesta tiiviisti 16/2017. Terveyden ja hyvinvoinnin laitos, Helsinki.

3. Ervasti J, Väänänen A, Leino-Arjas P, Johanna $\mathrm{K}$, Turunen J \& Varje P. Työkyvyn tuki edistää mielenterveyttä ja työhön osallistumista. Valtioneuvoston selvitys- ja tutkimustoiminnan artikkelisarja 24/2020. Helsinki. https:// tietokayttoon.fi/julkaisu?pubid=36401

4. TTL (Työterveyslaitos). Miten Suomi voi? https:// www.ttl.fi/tutkimushanke/miten-suomi-voi/https:// www.julkari.fi/bitstream/handle/10024/136021/ Ty\%c3\%b6n\%20muokkauksen $\% 20$ keinot $\% 2 c \% 20$ kun $\% 20$ mielenterveyden $\% 20$ h\%c3\%a4iri\%c3\%b6\%20vaikuttaa \%20 ty \% c3\%b6kykyyn.pdf? sequence=1\&isAllowed =y

\section{LAURa SALONEN}

VTM, Erikoistutkija

Turun yliopisto

Valtiotieteiden maisteri Laura Salosen väitöskirja

"Processes of long-term work disability and socioeconomic disparities. Unwinding the roles of family background, sickness absence, and psychosocial work environment" tarkastettiin Turun yliopiston Yhteiskuntatieteiden tiedekunnassa 8.10.2020. Vastaväittäjänä toimi dosentti Pauli Forma Varmasta ja kustoksena professori Mikko Niemelä Turun yliopistosta. 